\title{
THE PROLIFERATION OF FORENSIC SCIENCES AND EVI- DENCE BEFORE INTERNATIONAL CRIMINAL TRIBUNALS FROM A DEFENCE PERSPECTIVE
}

\begin{abstract}
The advent of forensic sciences at international criminal tribunals provokes scientific challenges, while confronting the judges and trial attorneys at the same time with the limitations of forensic sciences in international trials. This article discerns some of these challenges and limitations, which are pertinent to defence counsel, with a focus on the practice and jurisprudence of the International Criminal Court. It demonstrates that forensic evidence can have an impact on the probative value of the evidence, also at the level of international criminal tribunals. Adequate knowledge of the basics of forensic sciences and the principles which underpin this discipline can enable defence counsel to elicit potential exculpatory information at trial. For instance, certain new forensic techniques such as probabilistic genotyping can be quite persuasive to determine guilt or innocence. This article formulates practical recommendations for defence counsel operating at the International Criminal Court in approaching forensic evidence.
\end{abstract}

\section{THE UPCOMING ROLE OF FORENSIC SCIENCES AT INTERNATIONAL CRIMINAL TRIBUNALS}

The proliferation of forensic sciences at the level of international criminal tribunals, especially within the proceedings before the International Criminal Court ("ICC"), seems not to have attained the level of attention it receives in various domestic criminal jurisdictions.

* Professor of Politics of International Law, University of Amsterdam, Amsterdam, The Netherlands; Visiting Professor of International Criminal Law, Shandong University, Jinan, China; Defence counsel at the International Criminal Court; Lawyer, International Criminal Law, Knoops' International Lawyers, Amsterdam, The Netherlands. E-mail: office@knoops.info. 
Scarce publications on this subject matter may be found. ${ }^{1}$ Yet adequate knowledge thereof with the bench and with participants within the courtroom has become ever more important. As Laroche and Baccard observe, '... most international criminal trials contain at least an element of forensic evidence', while adding that 'forensic science has increasingly become a very useful tool and each international criminal tribunal has more or less developed forensic investigations'. ${ }^{2}$

The role of forensic science and expert witnesses must also be considered within the wider context of the law of evidence before international criminal courts and tribunals. Chambers of international courts and tribunals are not bound by strict procedural and evidentiary rules and have considerable discretion in their assessment of the admissibility and probative value of evidence, in contrast to some domestic jurisdictions. Yet, given its highly specialized and scientific nature, forensic expert evidence before international criminal tribunals nonetheless requires more narrow judicial supervision as to its forensic evidentiary quality. ${ }^{3}$

At the same time, the influx of forensic science and the evidentiary threshold to have forensic evidence admitted create potential defence opportunities and arguments, which, if the requisite knowledge is combined with adequate (cross) examination, could lead to exculpatory results in court.

One has to realise that the mentioned advent of forensic sciences at international criminal tribunals also provokes scientific challenges, while confronting the judges and trial attorneys at the same time with the limitations of forensic sciences at international trials. In this regard, Laroche and Baccard allude to these potential pitfalls of

\footnotetext{
${ }^{1}$ One of the few publications on forensic sciences at the ICC-level is authored by X. Laroche and E. Baccard, forensic consultants assigned at the Office of the Prosecutor of the ICC. See their publication 'International Courts and Forensic Sciences', in: J.A. Siegel and P.J. Saukko (eds.) Encyclopaedia of Forensic Sciences, Waltham: Academic Press (2013) vol 3, pp. 488-495.

2 Ibid., p. 489; See also J.P. Baraybar, 'The Need for a Scientific Advisory Unit', in M. Bergsmo, K. Rackwitz and T. Song (eds.), Historical Origins of International Criminal Law, vol 5, FICHL Publication Series No 24 (2017), pp. 173-174; P. Amann and M. P. Dillon, 'Electronic Evidence Management at the ICC: Legal, Technical, Investigative and Organizational Considerations', in A. BabingtonAshaye, A. Comrie and A. Adeniran, International Criminal Investigations, Eleven international publishing (2018), p. 232.

${ }^{3}$ M. Klinker, 'Forensic Science Expertise for International Criminal Proceedings: an old Problem, a new Context and a Pragmatic Resolution', 13 The International Journal of Evidence and Proof (2009), p. 125.
} 
forensic sciences at such trials, claiming that the scientific and legal challenges '.... are limiting the efficiency of forensic science within international criminal tribunals' ${ }^{4}$

It is therefore of perennial concern that defence counsel operating at international criminal tribunals are properly acquainted with the challenges and limitations of forensic sciences in this regard. For the defence, the proliferation of forensic sciences within international criminal trials imply to some extent the entering of uncharted waters.

This article discerns some of these challenges and limitations, which are pertinent to the defence counsel. To this end, one should first determine the question as to the formal limitations the application of forensic sciences may entail within the realm of international criminal trials (Section I). Furthermore, it will be assessed which challenges appear as to the qualification of forensic experts in court, also with regard to the forensic scientific standards (Sections II and III). Two areas of forensic sciences merit special attention since they may be instrumental in constituting a linkage between source and activity levels at international tribunals. These areas concern DNAevidence and wound ballistics (Sections IV and V).

In conclusion, this article will promulgate certain recommendations for defence counsel operating at the international criminal tribunals (Section VI).

\section{INTERPRETATIVE CHALLENGES OF FORENSIC SCI- ENCES FOR DEFENCE COUNSEL}

The role of forensic evidence is embedded in the broader discussion concerning the role of expert evidence before domestic and international criminal courts and tribunals. At the domestic level, the role of expert evidence varies based on whether the proceedings are partydriven, as in common law systems, or rather, appointed or instructed by the judiciary, as is more common in civil law jurisdictions. ${ }^{5}$ At the international level, expert evidence is appraised on the basis of established evidentiary and procedural rules, whose overriding purpose is to ensure that trials are fair and meet the requirements of justice. ${ }^{6}$

\footnotetext{
${ }^{4}$ X. Laroche and E. Baccard, supra note 1, p. 489.

${ }^{5}$ A. Singh, 'Expert Evidence', in K. Khan, C. Buisman and C. Gosnell, Principles of Evidence in International Criminal Justice, Oxford University Press (2010), p. 601.

${ }^{6}$ L. Freeman, 'Digital Evidence and War Crimes Prosecutions', 41 Fordham International Law Journal 2 (2018), p. 291.
} 
At the international level, given the scarce statutory framework with respect to the admission of evidence, international criminal judges have been given a broad discretion in matters of admissibility of (forensic) evidence. Regulation 44(5) of the ICC Regulations of the Court gives the power to the Chamber to inter alia 'issue any order as to ...the manner in which the evidence is to be presented'. This latitude appears to be at odds with the epistemic nature of expert evidence, as distinct from general factual or crime-based evidence. ${ }^{8}$

The way in which forensic experts should present expert evidence can actually not be dictated by the judiciary since it largely depends on an interpretation of a certain issue based on specific knowledge.

Generally, before the international criminal tribunals, the assessment of admissibility of expert (forensic) evidence follows a two-step test which includes the assessment of relevance and probative value including reliability and credibility - followed by a fairness or 'rights test', which may bar the consideration of otherwise admissible evidence. ${ }^{9}$ Whereas reliability 'speaks to the fact to which the testimony is directed', credibility 'refers to the truthfulness of a witness' testimony although the former may be seen as encompassing the latter. ${ }^{10}$ Such assessment is made on a case-by-case basis ${ }^{11}$ and ICC Chambers have favoured an approach whereby the final decision on evidentiary weight is made at the end of trial. The second step requires a weighing of 'the probative value of the evidence against its prejudicial effect', ${ }^{12}$ in other words, whether the prejudicial effect of otherwise probative evidence will adversely affect the fairness or expeditiousness of the proceedings, for instance, if it was obtained by means of a violation of internationally recognized human rights. ${ }^{13}$

${ }^{7}$ This power may be limited by Article 69(2) ICCS, which states that ' $[\mathrm{t}]$ he testimony of a witness at trial shall be given in person, except to the extent provided by the measures set forth in Article 68 ICC RPE, see A. Singh, supra note 5, p. 625.

${ }^{8}$ See A. Appazov, Expert Evidence and International Criminal Justice, Springer (2016), pp. 5-10.

${ }^{9} \mathrm{~K}$. Ambos, Treatise on International Criminal Law Volume III: International Criminal Procedure, Oxford University Press (2016) pp. 448-449, 485.

${ }^{10}$ Ibid., p. 472.

${ }^{11}$ Ibid., pp. 459, 472.

${ }^{12}$ See Prosecutor v. Lubanga, Corrigendum to Decision on the admissibility of four documents, 20 January 2011, ICC-01/04-01/06-1399, para. 31.

${ }^{13}$ K. Ambos, supra note 9, pp. 513-520; Rome Statute of the International Criminal Court, Article 69(7). 
Although international criminal chambers have considerable flexibility and discretion in assessing the admissibility of evidence, they are somewhat more limited with respect to expert evidence, such as forensic expertise, which requires adherence to stricter criteria, as discussed below. For example, a certain degree of specificity regarding an expert witness' sources and methods is required for effective cross-examination by opposing counsel, ${ }^{14}$ and could be a consideration upon assessing whether such evidence is admissible or not.

When one deals with the interpretative challenges of forensic sciences for defence counsel operating at international criminal tribunals, one touches upon its interpretative scope and the avenues forensic sciences offer to the bench and trial parties.

It is intriguing to observe that in the case against Jean-Pierre $B e m b a$, the ICC seemed to take an evidentiary position that was rather lenient to the prosecution when it came to prove its case forensically. The Court stated that:

...in case of mass crimes it may be impractical to insist on a high degree of specificity. In this respect, it is not necessary for the Prosecutor to demonstrate, for each individual killing, the identity of the victim and the direct perpetrator. Nor is it necessary that the precise number of victims be known. ${ }^{15}$

The question is really whether this assumption could be accepted; at least it triggers the question whether it impedes the defence counsel challenging the forensic evidence presented by the prosecution in such cases. From the analysis in this article, it follows that the view as endorsed in the Jean-Pierre Bemba case is contentious.

A prerequisite question, which is decisive for both prosecution and defence counsel, pertains to the scope of the forensic expertise at trial.

In essence this question comes down to determining to what extent a forensic scientist may offer '... an interpretation of the findings in the context of the case ....and deal with matters beyond ordinary knowledge and experience. ${ }^{16}$

${ }^{14}$ Ibid., p. 485; Prosecutor v. Lubanga, Judgment pursuant to Article 74 of the Statute, 14 March 2012, ICC-01/04-01/06-2842, para.112; Prosecutor v. Ngudjolo, Judgment pursuant to Article 74 of the Statute, 18 December 2012, ICC-01/04-02/123-tENG, para. 60; Prosecutor v. Katanga, Judgment pursuant to Article 74 of the Statute, 7 March 2014, ICC-01/04-01/07-3436-tENG, para. 94.

${ }^{15}$ Prosecutor v. Bemba Gombo, Decision pursuant to article 61(7)(a) and (b) of the Rome Statute on the charges of the prosecutor against Jean-Pierre Bemba Gombo, Pre-Trial Chamber II, ICC-01/05-01/08-424, 15/06/2009, para. 133.

${ }^{16}$ X. Laroche and E. Baccard, supra note 1, p. 491. 
Within forensic sciences, three interpretative levels of examination can be identified: For the defence counsel, but also for the bench and prosecution, the first and second level merit specific attention. The third level, the establishment of criminal guilt, does not pertain to the task of a forensic expert, who solely operates to assist the court on the first and second level. After all, a forensic expert may not usurp the role of the bench, being prohibited from invading the competence of the judge by virtue of the ultimate issue rule. ${ }^{17}$

This implies for instance that a military expert testifying on behalf of the prosecution cannot expound on a legal theme such as command responsibility, in order to give an opinion on which commander is to be held criminally responsible for certain crimes. The ultimate issue rule dictates that an expert is prevented from giving an opinion on the 'ultimate issue' of the case, which is the very issue that the court has to decide. ${ }^{18}$ An example from the practice of the International Criminal Tribunal for the Former Yugoslavia ("ICTY") is the case against Kordic and Cerkez, in which the prosecution sought to introduce a report written by a military analyst on the conflict in Bosnia-Herzegovina. This report, based on prosecution witness statements rather than on the expert's own observations, alluded to the alleged superior responsibility of the accused as military commander. The Trial Chamber ultimately excluded this evidence pursuant to the ultimate issue rule, considering that the expert was in fact invading the province of the court. ${ }^{19}$

Similarly, the ICC Chambers have concluded that an expert report or testimony may touch upon facts contested by the parties as long as they relate to the expert's expertise and does not usurp the role of the Chamber as the ultimate arbiter of fact and law. ${ }^{20}$ In the case of Ruto and Sang, the Chamber found that anticipated expert testimony

${ }^{17}$ R. May and M. Wierda, International and comparative Criminal Law Series, vol 9: International Criminal Evidence, Transnational Publishers Inc. (2002), p. 200.

${ }^{18}$ See Prosecutor v. Ruto and Sang, Decision on Sang Defence Application to Exclude Expert Report of Mr Hervé Maupeu, ICC-01/09-01/11-844, 7/8/2013, para. 12; Prosecutor v. Ntaganda, Decision on Defence Preliminary Challenges to Prosecution's Expert Witnesses, ICC-01/04-02/06-1159, 9/2/2016, para. 8; Prosecutor $v$. Ongwen, Decision on the Defence Request to Order a Medical Examination of Dominic Ongwen, ICC-02/04-01/15-637-Red, 16/12/2016, para. 19; Nahimana et al. v. Prosecutor, Appeals Chamber Judgment, ICTR-99-52-A, 28/11/2007, para 212.

${ }^{19}$ See Prosecutor v. Kordić \& Čerkez, ICTY Transcripts, IT-95-14/2, 28/01/2000, pp. 13289-13306.

${ }^{20}$ Prosecutor v. Ruto and Sang, supra note 18, para. 23; see also Prosecutor v. Ntaganda, supra note 18 , para. 8. 
which would qualify as usurping the functions of the Chamber by going into the 'ultimate issues' at trial include, for instance, 'opinions as to an accused guilt or innocence, or whether the contextual, material or mental elements of the crimes charged are satisfied'. ${ }^{21}$ The Chamber noted that anticipated testimony should not, directly or indirectly, address the role of the accused, or other key members of the alleged Network in the post electoral violence in Kenya. ${ }^{22}$ The Chamber further determined that it would be unduly restrictive to prohibit an expert from testifying about facts regarding the historical or political background of a case and that expert evidence relating to background issues which do not touch upon ultimate issues is therefore appropriate. ${ }^{23}$

For the prosecution and defence counsel, the most interesting level is the second interpretative level: the activity level. Here, the forensic expert is asked to discern what type of physical activity or process is likely to have caused the traces he or she has found at the first level.

Yet, a (second) prerequisite question is on what basis a forensic expert is to introduce and provide 'an interpretation of the findings' on this second level of examination?

Essential to such determination are three conditions:

i. The availability of two opposite hypotheses; one prosecution and one defence hypothesis;

ii. The availability of the requisite and balanced context-information from the case-file to enable the forensic expert to weigh the respective probabilities of these two hypotheses;

iii. The assurance that the chain of custody of the first level is not compromised (see Section IV).

For the defence counsel it will be vital to question a forensic expert in court about which hypotheses were at the basis of their opinion. In the event they were merely provided with one (the prosecutor's) hypothesis, the expert should, proprio motu examine any alternative theory which is permissible pursuant to the evidence.

In this regard, Laroche and Baccard, forensic consultants at the Office of the Prosecutor at the ICC, make the following observation:

\footnotetext{
${ }^{21}$ Prosecutor v. Ruto and Sang, supra note 18, para. 13.

${ }^{22}$ Prosecutor v. Ruto and Sang, supra note 18, para. 24.

${ }^{23}$ Ibid.
} 
The prosecution expert builds the forensic action plan according to international scientific standards; he shall verify, confirm, or exclude investigation's working hypothesis while exploring all other possibilities or explanations than the one put forward by the prosecution, including any alternative theory consistent with the scientifically demonstrated facts. ${ }^{24}$

The emphasis should be put on the verification with the experts whether they, explored ' $\ldots$ any alternative theory consistent with the scientifically demonstrated facts. ${ }^{25}$ For instance, if a (forensic) expert, on behalf of the prosecutor, has analysed a video allegedly depicting an armoured vehicle belonging to a certain armed group firing a grenade in a densely populated area, and is asked the question whether this footage is authentic, it is relevant that this expert is questioned in court on any other viable hypothesis. For example whether the alleged grenade could have been fired from another source. This would also raise questions as to the foundation of the expert's opinion that credence should be given to the prosecution's hypothesis and not so much the defence hypothesis or vice versa.

A scientifically based opinion on the probabilities of two hypotheses requires a statistical calculation or foundation. To this end, the theory and formula of the 18th century Englishman Thomas Bayes is to be used. This theory presumes that the probability of two hypotheses can be translated into a likelihood ratio (LR). This is the ratio of two evidentiary probabilities that are evaluated under different hypotheses. ${ }^{26}$ For instance: the prosecution's hypothesis is that a suspect is the source of a DNA trace and the defence hypothesis is that another, unknown person is the source of this DNA trace.

${ }^{24}$ X. Laroche and E. Baccard, supra note 1, p. 492.

${ }^{25}$ Ibid.

${ }^{26}$ P. Gill, Misleading DNA Evidence: Reasons for Miscarriages of Justice, Elsevier Inc. (2014), p. 17; S. de Smet, 'The International Criminal Standard of Proof at the ICC - Beyond Reasonable Doubt or Beyond Reason?', in C. Stahn, The Law and Practice of the International Criminal Court, Oxford University Press (2015), pp. 872-873; on the merits, demerits and consequences of applying Bayesian reasoning in forensic science for both experts and legal decision-makers, see M. Sjerps, 'Pros and Cons of Bayesian Reasoning in Forensic Science', in J.F. Nijboer and W.J.J.M. Sprangers (eds.), Harmonisation in Forensic Expertise, Amsterdam: Thela Thesis (2000), pp. 566-582. 
Bayes' theorem represents a mathematical formula for calculating the likelihood ratio, which is of considerable relevance in the field of forensic sciences. $^{27}$

According to this theory, the forensic researcher examines at the least two hypotheses which are mutually exclusive. At the outset of the examination each hypothesis bears a certain probability. The assessment of this probability, the so-called 'prior odds', is also based on the evidence which is presented apart from the forensic materials. Based upon his expertise, the forensic expert can determine the likelihood to obtain this evidence in case a certain hypothesis is true. $^{28}$

This is expressed by the formula: prior odds $\mathrm{x}$ likelihood ratio $=$ posterior odds.

A priori odds and a posteriori odds denote the different odds before and after certain (hypothesised) results have become known. In order to be able to ascertain the likelihood of a given hypothesis, the difference between a priori and a posteriori odds is crucial.

The likelihood ratio (LR) is thus the relation between the probability of hypothesis A and hypothesis B. The LR measures how persuasive the evidence is for hypothesis 1 , compared to hypothesis $2 .^{29}$

$(\mathrm{LR}=$ (probability of Hypothesis A/probability of Hypothesis $\mathrm{B})$

Two practical guidelines for defence counsel emerge from this analysis:

${ }^{27}$ S. de Smet, supra note 26, pp. 872-873; another pioneering figure with respect to adopting a scientific approach to evidence and exploring the logic of factual inference and probative value is the American jurist John Henry Wigmore who published, in 1913, The Principles of Judicial Proof as Given by Logic, Psychology, and General Experience and Illustrated in Judicial Trials, See P. Roberts and C. Aitken, 'Guide 3 'The logic of forensic proof: inferential reasoning in criminal evidence and forensic science', Royal Statistical Society (2014), pp. 66-70, online: http://www.rss.org.uk/ RSS/Influencing_Change/Statistics_and_the_law/Practitioner_guides/RSS/Influencing Change/Current_projects_sub/Statistics_and_the_law_sub/Practitioner_guides.aspx? hkey $=2$ cfdf562-361e-432e-851b-ef6ff52 $5414 \overline{5}$.

${ }^{28}$ See Netherlands Forensic Institute (NFI), professional appendix on Bayesian probabilistics (Vakbijlage De reeks waarschijnlijkheidstermen van het NFI en het Bayesiaanse model voor interpretatie van bewijs) Version 2.2, (May 201), p. 5, online: https://www.forensischinstituut.nl/publicaties/publicaties/2017/10/18/vakbij lage-waarschijnlijkheidstermen).

${ }^{29}$ Ibid. 
i. Firstly, it is quite relevant that defence counsel verifies whether a statistical calculation underlies the expert opinion, while questioning the forensic expert on the application of this theory.

ii. Secondly, it is of vital concern to ensure an exact formulation of the hypotheses since the values of the likelihood ratio and the prior odds are dependent on such formulation.

This is even more pertinent since, as noticed also by Laroche and Baccard, "[international criminal tribunals] may be increasingly confronted with statistical evidence, notably the Bayesian statistical approaches, which have become popular in DNA and many other branches of forensic science in recent years, ${ }^{30}$

Scholars such as Yvonne McDermott and Colin Aitken have argued that Bayesian probability theory could assist decision-makers in international criminal trials in complex fact-finding issues, for instance, by putting numerical values on a range of compounded probabilities. ${ }^{31}$ Applying such a model could 'enable judges to calculate probabilities in a manner that would be impossible on a straightforward reading of the trial record', in light of the volume and complexity of the evidence in international criminal trials. ${ }^{32}$ Given that reasoning in the context of international criminal trials is 'inherently probabilistic', the authors argue that an understanding of the principles underpinning Bayesian Networks ${ }^{33}$ and its utilisation in practice, 'have the potential to strengthen judges' confidence in their findings, to assist lawyers in preparing for trial [eg. to evaluate the sufficiency and robustness of the evidence], and to provide a tool for the assessment of international criminal tribunals' factual findings'. ${ }^{34}$ Bayesian Networks are not meant to substitute legal reasoning, but rather, can serve as a tool to illustrate and evaluate the association between items of evidence and propositions. ${ }^{35}$ Bayesian Networks could further enable judges to enunciate more precisely the applicable standards of proof - which hitherto remain elusive at the different stages of proceedings at the International Criminal Court -

\footnotetext{
${ }^{30}$ X. Laroche and E. Baccard, supra note 1, p. 493.

${ }^{31}$ Y. McDermott and C. Aitken, 'Analysis of evidence in international criminal trials using Bayesian Belief Networks', Law, Probability and Risk (2017) 16, 111 at 116.

32 Ibid., p. 113.

${ }^{33}$ Ibid., p. 112.

${ }^{34}$ Ibid., p. 113.

${ }^{35}$ Ibid., p. 115.
} 
and whether the evidence meets the appropriate standard. ${ }^{36}$ Given the relevance of this theory for strengthening fact-finding before international criminal courts and tribunals, the authors' suggestion that applying the Bayesian probability theory should not be limited to the interpretation of DNA evidence is defensible and well-founded.

Bayes' theory can also be transposed to judicial review before international criminal jurisdictions and can serve as an objective standard to assess the trier of fact's margin of appreciation. ${ }^{37}$ For instance, Bayes' theory was raised on appeal by the Defence in the Prosecutor v Lukić et al. case at the ICTY. The defence argued that Bayesian logic was instructive to the facts and evidence of the case, particularly with respect to Sredoje Lukić' alibi defence and his disputed presence at the alleged crime scenes. Applying Bayes' theory, the defence sought to demonstrate that the Trial Chamber erred in its assessment of the evidence by arguing that a reasonable alternative with a high likelihood was provided by the defence, yet ignored by the Trial Chamber. ${ }^{38}$ The defence stressed the importance for the Chamber and parties to explore alternative hypotheses and argued that the Trial Chamber's reasoning lacked a proper likelihood ratio and could not be justified as the only reasonable inference. ${ }^{39}$

The Bayesian model is not only used for DNA-investigation; this theory could be applied in many fields of forensic research whereby the interpretation of the result is dependent on uncertain factors. ${ }^{40}$ For instance, it is well-suited to interpret and challenge digital forms of evidence to which criminal trials are increasingly confronted, particularly at the ICC, such as video and audio recordings,

\footnotetext{
${ }^{36}$ Ibid., pp. 114-115.

37 Prosecutor v. Lukic et al., Lukic Defence Appeal Brief, ICTY, IT-98-32/1, 2/11/ 2009, para. 23.

38 Ibid.

39 Ibid., para. 31.

${ }^{40}$ See Netherlands Forensic Institute (NFI), supra note 28; S. de Smet, supra note 26, p. 872; C. Aitken, P. Roberts, G. Jackson, 'Communicating and Interpreting Statistical Evidence in the Administration of Criminal Justice: Practicioner Guide 1. Fundamental of Probability and Statistical Evidence in Criminal Proceedings', Royal Statistical Society (2010), pp. 43-52, online: http://www.rss.org.uk/RSS/Influencing Change/Statistics_and_the_law/Practitioner_guides/RSS/Influencing_Change/Current_ projects_sub/Statistics_and_the_law_sub/Practitioner_guides.aspx?hkey = 2cfdf562-361 e-432e-851b-ef6ff5254145.
} 
telecommunications data, and social media. ${ }^{41}$ The proliferation and rapid evolution of forensic technologies present new opportunities but also new challenges for the Defence, Prosecution, Victims' representatives and judges alike. Bayes' model of quantitative and probabilistic calculations can enable all actors involved in the judicial process to capably engage with vast amounts of digital evidence.

Emphasizing the relevance of statistics and science in the field of criminal law, the United Kingdom Royal Statistical Society publishes practitioner guides intended to 'assist judges, lawyers, forensic scientists and other expert witnesses in coping with the demands of modern criminal litigation. ${ }^{42}$ The guides allow practitioners to gain a deeper understanding of the fundamentals of probability and statistical evidence in criminal proceedings including testing the probative value of DNA evidence, understanding the logic of forensic proof and inferential reasoning and interpretation of expert evidence. ${ }^{43}$

The necessity that defence counsel acquire some basic knowledge of these theories transpires in the observation by the two mentioned forensic consultants, affiliated with the Office of the Prosecutor at the ICC, saying that, 'on the other hand, it appears that probability and statistics are not always handled confidently and competently, by lawyers, judges or even by forensic scientists'. ${ }^{44}$

As articulated by Simon de Smet with respect to the Bayesian model and probability theory: '[a]lthough the mathematics involved may be rather daunting to many lawyers, modern computer programs can offer assistance with this. ... There is no principled reason why courts could not apply Bayesian epistemology if they so wanted. In fact, the great rigour and perfect transparency of the model are two attributes that advocate strongly in its favour'. ${ }^{45}$

${ }^{41}$ For instance, Prosecutors at the Special Tribunal for Lebanon rely in major part on telecommunications evidence; the Prosecutor v. Bemba et al. case at the ICC also focused to a major extent on call data records, telephone intercepts by Dutch authorities, and financial records emanating from Western Union, see L. Freeman, supra note 6, 289, 293.

${ }^{42}$ Royal Statistical Society Practitioner guides webpage, online: http://www.rss. org.uk/RSS/Influencing_Change/Statistics_and_the_law/Practitioner_guides/RSS/ Influencing_Change/Current_projects_sub/Statistics_and_the_law_sub/Practitioner_ guides.aspx?hkey =2cfdf562-361e-432e-851b-ef6ff5254145 [consulted 22 May 2018].

${ }^{43}$ Ibid.

${ }^{44}$ X. Laroche and E. Baccard, supra note 1, p. 493 ; S. de Smet, supra note 26, pp. 872-873.

${ }^{45}$ S. de Smet, supra note 26, p. 872. 


\section{TESTING FORENSIC SCIENCES IN COURT BY DEFENCE COUNSEL}

\subsection{Generally Accepted Criteria to Test Forensic Sciences in Interna- tional Criminal Law}

As a result of the aforegoing, another prerequisite arises to accept forensic sciences at the level of international criminal tribunals. This requirement pertains to the qualification of forensic experts and the testing of the reliability of this type of evidence. This section identifies the main criteria used to test forensic sciences in criminal cases, which are derived from US law and which now seems to constitute a consensus within forensic community and transpire into international criminal cases.

As to the first element, the competence of forensic experts, resort should be had to the landmark ruling of the U.S. Supreme Court in 1993 in Daubert vs. Merrell Dow Pharmaceuticals, Inc. ${ }^{46}$

The claimants in this case, two minor children and their parents, filed a law suit against Merrell Dow Pharmaceuticals, saying that the childrens' serious birth defects had been caused by the mothers' prenatal ingestion of Bendectin, a prescription drug marketed by Merrell Dow. The California District Court refused this claim, basing its ruling on the opinion of an expert who, having reviewed the extensive published scientific literature on the subject, came to the conclusion that maternal use of Bendectin had not been shown to be a risk factor for human birth defects. Yet, the claimants presented their case based upon the testimony of eight other well-credentialed experts, who did conclude that Bendectin could cause birth defects. Their findings relied on animal studies, chemical structure analyses, and the unpublished 'reanalysis' of previously published human statistical studies. However, the court held that this evidence did not meet the applicable 'general acceptance' standard for the admission of expert testimony. The Court of Appeals upheld this ruling. It opined, citing Frye v. United States, 54 App. D. C. 46, 47, 293 F.1d 13, 1014, that expert opinion based on a scientific technique is inadmissible unless the technique is 'generally accepted' as reliable in the relevant scientific community. ${ }^{47}$

In the pioneering Daubert judgment, which lies at the foundation of contemporary forensic norms in regard to the admissibility of

\footnotetext{
${ }^{46}$ Daubert v. Merrell Dow Pharmaceuticals, Inc., 509 U.S. 579 (1993).

${ }^{47}$ Ibid.
} 
forensic evidence, the US Supreme Court justices set forth the criteria according to which the reliability and credibility of forensic evidence produced by a forensic expert should be assessed. These criteria are the following:

- Has the theory of technique used been tested?

- Was it subject to peer review?

- What is the error rate?

- Do scientific standards exist and were they maintained?

- Was this standard widely accepted in scientific community?

- Does an internationally accepted norm exist?

- Was the norm applied properly? ${ }^{48}$

This list of criteria, which has been adapted and applied by various domestic and international jurisdictions and evolved into widely accepted contemporary forensic norms as to the qualification of a forensic expert, ${ }^{49}$ can also serve as a checklist for defence counsel appearing before international criminal tribunals. Yet, the way the admissibility and reliability of forensic sciences is to be determined may vary depending on the underlying law system.

\subsection{Admissibility and Reliability Tests in a Comparative Perspective}

In the UK, the Law Commission has proposed measures for reform in the English and Welsh courts' current approach to expert evidence; based on an extensive study, the Law Commission postulated that the safeguards for testing the reliability and weight of expert evidence common to most common law jurisdictions - cross-examination, the adduction of contrary expert evidence and judicial guidance at the end of a jury trial,-- particularly with respect to more scientific and technical fields, are insufficient. It recommended special rules to test the admissibility of expert evidence, in light of the particular nature

\footnotetext{
${ }^{48}$ See also X. Laroche and E. Baccard, supra note 1, p. 491; A. Appazov, supra note 8, pp. 123-132; W. Schabas, The UN International Criminal Tribunals: The Former Yugoslavia, Rwanda and Sierra Leone, Cambridge University Press: Cambridge (2006), p. 480.

${ }^{49}$ See inter alia Judgment Supreme Court of the Netherlands, ECLI:HR:1998:ZD0917, 27/01/1998; drawing from the Daubert criteria; Judgment of the Supreme Court of Canada, R. v. J.-L.J., [2000] 2 S.C.R. 600, para. 33; R. v. Trochym, [2007] 1 SCR 239, para. 26; Prosecutor v. Sesay et al., Judgment, SCSL-0415-T, 25 February 2009, para 27.
} 
of expert evidence, including the fact that experts can provide opinion evidence on matters outside of most judges' or jurors' knowledge and expertise. $^{50}$

In the French legal system, the reliability of expert witnesses tends to be more implicit, as he or she is typically appointed by the instructing judge or the court and chosen from a list. ${ }^{51}$ Expert reports are typically examined at the pre-trial stage and the expert's qualifications are established at the time of his or her registration in the Court of Cassation's list of experts. ${ }^{52}$ The German system presents similar characteristics in that experts are appointed and instructed by the court, drawing from a register of accredited experts. ${ }^{53}$

\subsection{Admissibility and Reliability Tests at the International Criminal Court}

At the international ad hoc tribunals and the ICC, expert evidence is judge-driven and therefore more akin to the civil law traditions. ${ }^{54}$ The Statute of the International Criminal Court, its Rules of Procedure and Evidence, and even the Regulations of the court are silent on delineating what the term 'expert witness' entails, and what scientific standards ought to be applicable at the ICC. The only modest exception to this silence is ICC Regulation 44, which obliges the Registrar to compile and maintain a list of experts accessible to all organs and participants of the court proceedings. Regulation 56 of the Regulations of the Registry provides that for the purposes of Regulation 44 of the Court, candidates applying for inclusion on the list of experts must provide a detailed curriculum vitae, proof of qualifications, indication of expertise in a relevant field, and where applicable, a statement of whether he or she is included in any list of experts acting before any national court.

The Trial Chamber in Lubanga provided further clarifications with respect to Regulation 44 by indicating that 'the list should include a wide selection of experts, all of whom will have had their qualifica-

${ }^{50}$ UK Law Reform Commission, Expert Evidence in Criminal Proceedings in England and Wales, Law Com No 325 (21 March 2011), presented to Parliament pursuant to section 3(2) of the Law Commissions Act 1965, https://assets.publishing. service.gov.uk/government/uploads/system/uploads/attachment_data/file/229043/ 0829, pdf.

${ }^{51}$ A. Singh, supra note 5, p. 601; A. Appazov, supra note 8, p. 157.

52 A. Appazov, supra note 8, p. 157.

${ }^{53}$ A. Appazov, supra note 8, pp. 161-162.

${ }^{54}$ A. Singh, supra note 5, p. 602. 
tions verified; moreover, they will have undertaken to uphold the interests of justice when admitted to the list'. ${ }^{55}$ The Chamber also reminded the Registrar that the list should have regard to equitable geographical representation and a fair representation of female and male experts, as well as experts with expertise in trauma, including trauma related to crimes of sexual and gender violence, children, elderly, and persons with disabilities among others. ${ }^{56}$ The Court has also favoured the joint instruction of expert witnesses by parties, as 'through the exercise of identifying with precision the real areas of disagreement between the parties, the expert will be placed in the best possible position to achieve a balanced and comprehensive analysis' ${ }^{57}$ In such cases, by appointing a jointly or judicially instructed expert, the Trial Chamber would appear to be making an assessment on the expert's qualifications and impartiality. ${ }^{58}$

It is therefore of paramount importance that defence counsel, confronted with expert witnesses derived from the mentioned list, test the competence of each expert, led by the aforegoing Daubert criteria. The same counts for experts not appearing on this list, as the list as such is not imperative to appear in court as an expert. ${ }^{59}$

Even though Regulation 44 provides an invaluable safeguard as to the quality of experts at the ICC, it does not promulgate much clarity as to what actually defines an expert witness. ${ }^{60}$ Even the definition of an expert witness as formulated by the ICTY being a '.. person who by virtue of some specialized knowledge, skill or training can assist the trier of fact ... ${ }^{61}$ does not enlighten the practical implications of how to deal with the competence of expert witnesses at trial. It is for this reason that the Daubert criteria could substitute for this substantial hiatus.

${ }^{55}$ Prosecutor v. Lubanga, Decision on the procedures to be adopted for instructing expert witnesses, Trial Chamber I, ICC-01/04-01/06-1069, 10/12/2007, para 24.

${ }^{56}$ Ibid.

${ }^{57}$ Prosecutor v. Bemba, Decision on the procedures to be adopted for instructing expert witnesses, ICC-01/05-01/08-695, Trial Chamber III, 12/2/2010, paras. 11-12, citing Prosecutor v Lubanga, supra note 55, paras. 14-23.

${ }^{58}$ A. Singh, supra note 5, p. 608.

59 Prosecutor v. Lubanga, supra note 55, para. 25; see X. Laroche and E. Baccard, supra note 1, p. 491.

${ }^{60}$ X. Laroche and E. Baccard, supra note 1, p. 491.

${ }^{61}$ Eg Prosecutor v. Stanislav Galić, ICTY Trial Chamber I, Decision Concerning the Expert Witnesses Ewa Tableau and Richard Philipps, IT-98-29-T, 03/07/2002; Prosecutor v. Ntaganda, supra note 18, para. 7. 
As evidenced by the Pre-Trial Chamber's approach in Bemba, above, judges have not only taken a flexible approach to the admission of evidence but have applied a seemingly low forensic evidentiary threshold, particularly with respect to crime-based evidence. ${ }^{62}$

\section{GUIDELINES TO (CROSS) EXAMINE AND TEST FORENSIC EXPERT AT TRIAL BY DEFENCE COUNSEL}

Based upon the leading Daubert criteria, which have been adopted in various domestic jurisdictions, ${ }^{63}$ the following four main guidelines for defence counsel can be set forth when testing an expert witness regarding his qualifications:

i. What is the knowledge and skill of the person of the expert?

ii. What is the validity and reliability of the applied method?

iii. Did the expert have experience with this method?

iv. What was the manner in which the method was applied by the expert in the present case to the acquired data?

A fifth criterion relates to verifying the way the forensic evidence was collected. The collection is contingent upon the chain of custody. Although neither the ICC Statute nor the statutes of the ad hoc tribunals refer to the requirement of the preservation of the chain of custody, not even in their respective Rules of Procedure and Evidence, the Regulations on the ICC Prosecutor oblige the prosecutor to secure the (forensic) evidence by way of an '... uninterrupted chain of custody of documents and all other types of evidence. All evidence shall constantly be in the possession of the collector or the individual authorised to have possession of the item. The maintenance of the chain of custody shall be recorded and managed in accordance with regulation 23 , ${ }^{64}$

Typically, domestic legal systems impose various possible legal consequences in case the chain of custody is compromised, such as exclusion of inculpatory evidence. An example of this can be found in the case of the murder of Meredith Kercher in Perugia (Italy) in 2007. The case became widely known for one of the defendants, Amanda

\footnotetext{
${ }^{62}$ R. May and M. Wierda, supra note 17, p. 52; M. Klinker, supra note 3, 127.

${ }^{63}$ See supra note 49.

${ }^{64}$ See regulation 22 of the Regulations of the Office of the Prosecutor (2009), ICCBD-05/01/09; P. Amann and Mark. P. Dillon, supra note 2, pp. 237-248.
} 
Knox, an American national. In the course of the criminal proceedings, which lasted from 2007 to 2015, experts found that multiple pieces of evidence had not been handled properly by police investigators, in disregard of standard principles on the correct approach of a crime scene; several omissions by investigators in this respect, which amounted to an interruption of the chain of custody, entailed the contamination of crucial forensic materials. ${ }^{65}$ These expert findings, amongst other factors, eventually led the Italian Court of Cassation to find the evidence to be unreliable, which necessitated the exoneration of the convicts. ${ }^{66}$ This example emphasizes the importance of compliance with the chain of custody in handling forensic evidence.

The question arises as to what could be the legal consequences of the chain of custody being interrupted and not recorded within ICC proceedings. The ICC Chambers have found that in order to assess documentary evidence the Chamber must examine its 'provenance, source or author, as well as their role in the relevant events, the chain of custody from the time of the item's creation until its submission to the Chamber, and any other relevant information. ${ }^{67}$ To date, no clear precedent thereto exists at the ICC with respect to the interruption of the chain of custody even though no viable reason can be found why such interruption should not incur a consequence similar to the one which was adopted in the Amanda Knox case, as the underlying forensic issues remain the same. By contrast to the domestic legal systems, exclusion of evidence is infrequent before international criminal jurisdictions, where judges have favoured admitting an item of evidence and making a determination on admissibility at the time of the judgment. ${ }^{68}$ However, as recently noted by Lindsay Freeman, there has, in recent years, 'been a notable increase in the exclusion of evidence, particularly for items of new media that have not been properly sourced', which is a partial reflection of the challenges posed by new types of evidence. ${ }^{69} \mathrm{~A}$

\footnotetext{
${ }^{65}$ P. Gill, supra, note 26, pp. 136-158.

${ }^{66}$ Italian Corte di Cassazione, 36080/15, Judgment 27/03/2015 (the Italian text of the judgment can be found here: http://www.giurisprudenzapenale.com/wp-content/ uploads/2015/09/cass-pen-2015-36080.pdf).

${ }^{67}$ Prosecutor $v$ Bemba, Judgment pursuant to Article 74 of the Statute, Trial Chamber III, ICC-01/05-01/08-3343, 21 March 2016, para. 247.

${ }^{68}$ L. Freeman, supra note 6, 293.

${ }^{69}$ L. Freeman, supra note 6, 293, citing Prosecutor $v$ Bemba, Decision on the Admission into Evidence of Items Deferred in the Chamber's «Decision of the Prosecution's Application for Admission of Materials into Evidence Pursuant to
} 
forensic scientist who is not assured of a preserved chain of custody should refrain from providing an opinion about the probabilities of the hypothesis, or at the least should implement this factor in his statistical calculation. Therefore, this aspect needs to be further developed at the ICC to meet the challenges forensic sciences create.

A verification by defence counsel operating at international criminal tribunals of the chain of custody is even more relevant in light of the fact that in most instances crime scene investigations within these trials '... take place well after the crime has been committed ...', which '... exacerbates the intrinsic limitations of forensic science'. ${ }^{70}$ One important question for cross-examination of a forensic expert is therefore whether he or she was able to ascertain the chain of custody of the piece of evidence he or she examined.

Furthermore, regulation 24 of the ICC Prosecution Regulations merits attention. This regulation entails three important forensic guidelines for the prosecutor:

i. To develop and apply a consistent and objective method for the evaluation of sources and (forensic) evidence;

ii. To take into account the credibility and reliability of such sources and evidence;

iii. To examine this evidence 'from multiple sources as a means of bias control'.

These three elements can also serve as fundamentals for defence counsel cross examination. Also here, the regulation is silent as to what potential legal consequences an infringement thereof would encompass. Yet, especially the obligation to evade 'bias' should be a topic for cross-examination for defence counsel.

This last element of regulation 24 coincides with the forensicprofessional obligation of an expert to ascertain alternative theories which do not conflict with the evidence. ${ }^{71}$

Footnote 69 continued

Article 64(9) of the Rome Statute », Trial Chamber III, ICC-01/05-01/08-2721, 27/ 06/2013.

${ }^{70}$ X. Laroche and E. Baccard, supra note 1, p. 491; on the limits of international criminal investigations, see N. Combs, 'Grave Crimes and Weak Evidence: FactFinding Evolution in International Criminal Law', 58 Harvard International Law Journal 1 (2017), pp. 48-49; R. Cryer et al., An Introduction to International Criminal Law and Procedure, Cambridge University Press (2016), pp. 449-450.

${ }^{71}$ X. Laroche and E. Baccard, supra note 1, p. 493. 
As an overall conclusion of this section, it can be said that defence counsel should be mindful to examine the forensic expert as to whether he or she was instructed to assess the evidence based upon different theories and which sources were made available to him or her by the prosecution.

\section{CONTEMPORARY AREAS OF FORENSIC SCIENCES RELEVANT TO DEFENCE COUNSEL AT THE INTER- NATIONAL CRIMINAL TRIBUNALS}

Modern forensic science entails several challenges and, at the same time, opportunities for defence counsel. Two examples may illustrate this.

\subsection{DNA Developments Relevant to Defence Counsel}

The first example pertains to the advent of new DNA technology which may be beneficial also for defence counsel at international criminal tribunals. The application of DNA techniques at the level of international criminal tribunals is presented as mainly relevant for establishing the identities of alleged victims of international crimes and not so much as to ascertain evidence of (in)direct perpetration. ${ }^{72}$

Yet in some situations, modern DNA technology can serve as a potential exculpatory instrument for defence counsel. One example is that of rape in armed conflicts by alleged multiple perpetrators whereby the national authorities collected forensic evidence by way of extractions of semen from the victim's body, resulting in complex mixed DNA profiles.

The problem with the identification of contributors to such profiles is that its determination depends on an interpretation of the profiles by the DNA-analyst, which might imply a rather subjective element.

In recent years a new DNA technology was developed: probabilistic genotyping.

Kaye describes this technique as follows:

Probabilistic approaches provide a statistical weighting to the different genotype combinations. Probabilistic genotyping does not utilize a stochastic threshold. Instead, it incorporates a probability of alleles dropping out or in. In making use of more genotyping information when performing statistical cal-

${ }^{72}$ X. Laroche and E. Baccard, supra note 1, pp. 489-490. 
culations and evaluating potential DNA contributors, probabilistic genotyping enhances the ability to distinguish true contributors and noncontributors. ${ }^{73}$

For defence counsel, the differentiation between 'true contributors and non-contributors' can constitute the difference between guilt and innocence.

An example from legal practice demonstrates the importance of this methodology in criminal law. The example relates to a case in which the American DNA expert Dr. Greg Hampikian and his team were instrumental in redressing a miscarriage of justice with respect to two convicted individuals, Darryl Pinkins and Roosevelt Glenn. In the early $1990 \mathrm{~s}$, Mr. Pinkins and Glenn were convicted for a multiple-attacker rape in Indiana (U.S.) based upon a DNA analysis using standard DNA techniques, which resulted in the conclusion that their DNA was present in the mixed DNA profile. ${ }^{74}$ The prosecution initially intended to develop profiles from at least four semen contributors: yet, based on these standard techniques, the prosecution was only able to produce two major profiles. Some years later, Dr. Hampikian and his team, led by the electronic DNA data, reexamined the DNA mixture based upon probabilistic genotyping. These experts were now able to develop four male profiles and all of these profiles did exclude Mr. Pinkins and Mr. Glenn. As a result, the U.S. prosecutor, accepting this new evidence, agreed to exonerate them. ${ }^{75}$

In order to understand why this exoneration could be realized, one has to understand the essence of this new technology. Again, the following explanation given by Kaye is helpful:

A probabilistic genotyping system is comprised of software, or software and hardware, with analytical and statistical functions that entail complex formulae and algorithms. Particularly useful for low-level DNA samples (i.e., those in which the quantity of DNA for individuals is such that stochastic

\footnotetext{
${ }^{73}$ D.H. Kaye, 'Forensic Science, Statistics \& the Law: SWGDAM Guidelines on "probabilistic Genotyping Systems" (part 2)', 25/10/2015, online: http://for-sci-law. blogspot.nl/2015/10/guidelines-on-probabilistic-genotyping.html?m =1.

${ }^{74}$ M. Possly, 'The National Registry of Exonerations (a project of the Newkirk Center for Science \& Society at University of California Irvine, the University of Michigan Law School and Michigan State University College of Law)', https://www. law.umich.edu/special/exoneration/Pages/casedetail.aspx?caseid $=4874 \quad$ (Darryl Pinkins) and https://www.law.umich.edu/special/exoneration/Pages/casedetail.as px?caseid $=5087$ (Roosevelt Glenn).

${ }^{75}$ Ibid.
} 
effects may be observed) and complex mixtures (i.e., multi-contributor samples, particularly those exhibiting allele sharing and/or stochastic effects), probabilistic genotyping approaches can reduce subjectivity in the analysis of DNA typing results. ${ }^{76}$

Actually, this description shows the practical relevance of this methodology for both prosecution and defence counsel in cases of:

i. Low-level DNA samples, and

ii. Complex DNA mixtures.

Importantly, as Kaye expresses, 'the use of likelihood ratio as a reporting statistic for probabilistic genotyping differs substantially from binary statistics such as the combined probability of exclusion' ${ }^{77}$ Defence counsel should thus be aware of this distinction. They should also understand that probabilistic genotype programs produce genotypes with calculated probabilities which can be used in likelihood calculations for inclusions, and also compare those profiles to known profiles from defendants and victims to determine a potential exclusion as contributor.

Another area which exhibits considerable technological advances with respect to DNA evidence relates to secondary transfer - an occurrence whereby DNA is transferred from one object or person to another via an intermediate object or person. Recent developments in more sensitive technologies increase the likelihood of obtaining results from low quality samples. ${ }^{78}$ Secondary transfer should be of concern to DNA analysts and Defence counsel alike as '(i) it could falsely link someone to a crime; (ii) it could introduce extraneous DNA, or foreign DNA, into a forensic sample; (iii) it could lead analysts and other medicolegal professionals to falsely conclude that DNA left on an object is a result of direct contact'. ${ }^{79}$

At the level of international criminal tribunals, the potential availability of DNA profiles and electronic DNA data, preserved after a particular armed conflict, can be relevant for the defence. Especially in cases such as sexual offences, these data must be peer reviewed on the basis of modern DNA methodology such as probabilistic genotyping. Moreover, the phenomenon of secondary

${ }^{76}$ D.H. Kaye, supra note 73.

${ }^{77}$ Ibid.

${ }^{78}$ C. Cale et al., 'Could Secondary DNA Transfer Falsely Place Someone at the Scene of a Crime?', 61 Journal of Forensic Sciences 1, (January 2016), p. 196.

${ }^{79}$ Ibid. 
transfer can also feature at this level vis- $a$-vis challenging charges pertaining to sexual offences.

\subsection{Wound Ballistic from a Defence Perspective}

At international criminal trials, the prosecution is often relying on medicolegal analyses resulting from the exhumation of alleged mass graves in order to determine, inter alia, the cause of death. ${ }^{80}$

The discipline of wound ballistics, to be distinguished from ammunition ballistics, may be pivotal in both inculpatory but also exculpatory sense. The Trial Chamber in Katanga and Ngudjolo at the ICC assessed a ballistic expert report submitted by the Prosecution, and determined that it had 'limited value for obtaining a better understanding of the case'. ${ }^{81}$ On this basis, the Chamber did not authorize the Prosecution to include the ballistic report to the List of Incriminating evidence and instructed the Prosecution, rather, to communicate it to the Defence under Rule 77 of the Rules of procedure and Evidence as it contained information that is potentially relevant to the Defence'. 82

While ammunition ballistics deals with the behaviour of projectiles, wound ballistics is meant to determine the relationship between a certain projectile and a specific injury.

Wound ballistics as such may, at the level of international criminal tribunals, specifically be relevant to establish an alleged linkage between wounds inflicted by projectiles and potential armed factions or groups which are involved in a specific armed conflict, which forms part of the trial proceedings.

Determinative for such linkage may be an assessment of the type of ammunition and/or weaponry used by these armed groups or military force to which a defendant allegedly belongs.

For instance, in certain civil wars, armed groups are supplied with AK-47 rifles, one of the most common weapons in the world. Once it is the prosecution's case that a certain (para)military group is

\footnotetext{
${ }^{80}$ See for this relevance C. Fournet, 'Forensic Sciences (anthropology/archaeology/pathology) and international criminal justice', in: Elsevier, Science and Justice 56 (2016), p. 303 referring to the ICTY Trial Chamber Judgements of Prosecutor $v$ Radislav Krstić, IT-98-33, 2/8/2001 and Prosecutor v. Radovan Karadžić, IT-95-5/18T, 24/3/2016.

${ }^{81}$ Prosecutor v. Katanga and Chui, Decision on the disclosure of evidentiary material relating to the Prosecutor's site visit to Bogoro on 28, 29 and 31 March 2009, ICC-01/04-01/07-1515-Corr, 7/10/2009, para. 44.
}

${ }^{82}$ Ibid., paras. $41-45$. 
equipped with this kind of weaponry and responsible for killing civilians while producing autopsy reports showing that civilians were killed by 'high explosive projectiles', defence counsel representing an alleged military leader of such a group might elicit exculpatory information from the prosecution forensic expert on the basis of wound ballistic knowledge. To this end, one needs to be familiar with some basics of wound ballistics, such as the path and nature of tissue disruption caused by an AK-47 projectile as opposed to, for instance, the path of tissue disruption caused by a $7.62 \mathrm{~mm}$ projectile which is used in sniper rifles and machine guns. The former projectile (AK-47) creates a $25-\mathrm{cm}$ path of relatively minimal tissue disruption before the projectile begins to yaw, while the latter projectile, after having travelled about $16 \mathrm{~cm}$ into the body, starts to yaw through $90^{\circ}$ and then travels base forward ${ }^{83}$ Defence counsel, based upon such basic understanding of wound ballistics, could accordingly examine the prosecution's expert on such types of (tissue) disruption, which has the potential of disconnecting the defendant from a certain crime scene.

Few studies illustrate the importance to differentiate at international criminal tribunals between the various calibres of weaponry and ammunition. One of them, which underpins the relevance for defence counsel to examine a forensic pathologist or ballistic expert testifying for the prosecution, on this subject, is a 1991 study published by three surgeons. The data of these authors are based upon their medical intervention with respect to 299 patients who sustained ballistic injuries to the abdomen between July 1983 and June 1987, resulting from the Lebanese conflict and civil war that started in the early 1970's. During this conflict a different array of weapons was used. This study, which was conducted at the American University of Beirut Medical Centre, evaluates the extent of injury by either bullets or shell fragments. ${ }^{84}$

Based upon this review of 299 patients who sustained penetrating ballistic trauma to the abdomen, the resulting data '(...) suggest that high energy bullets to the abdomen cause higher tissue penetration

${ }^{83}$ Emergency War Surgery: 4th United States Revision, Borden Institute US Army Medical Department Center and School Fort Sam Houston, Texas Office of The Surgeon General United States Army Falls Church, Virginia (2013), Chapter I: Weapons Effects and War Wounds, online: http://aumf.net/wp-content/uploads/ 2016/07/emergencywarsurgery-us.pdf.

${ }^{84}$ B.A Georgi, M. Massad and M. Obeid, 'Ballistic Trauma to the Abdomen: Shell Fragments Versus Bullets', 31 The Journal of Trauma 5 (1991), pp. 711-716. 
and a greater blast effect than shell fragments' ${ }^{85}$ The study indicates that patients with shell fragment injuries probably sustain lower energy missile injury to the abdomen. The findings of this study were supported by ballistic reports.

Therefore, once the prosecution submits reports into evidence from a pathologist who concludes that a certain victim was killed by a - high explosive - projectile, a cross-examination of such expert in court in order to ascertain whether this expert was able to make the differentiation in terms of linkage to a certain type of ammunition, is worthwhile. This might especially be the case when the discussion at trial also revolves around the use of mortar fire versus hand weaponry by armed groups.

A second relevant aspect of wound ballistics for defence counsel concerns the methodology applied by forensic experts performing post-mortem autopsies on alleged victims of armed conflicts. When during these autopsies metallic fragments are detected in the body of an alleged civilian, the prosecution might use these findings to sustain its theory that such a person was a victim of violation of the laws of war.

Yet, such general observations cannot in and of themselves serve as evidence for the cause of death as being related to the alleged lethal nature of such fragments.

Such a conclusion is ultimately contingent upon what type of graphical method is used to document the injured area of the body surface and what methodology is applied to locate the precise position of the projectile or fragment.

Apart from traditional methods such as surface documentation (eg photographs) and radiological documentation (eg X-ray), contemporary wound ballistic methods entail 3-D graphic techniques and laser scanning of the body and crime scene, while reconstructing the crime scene and injuries to the body. ${ }^{86}$

In order to adequately cross-examine a forensic expert on this field, defence counsel should be conscious that the evidentiary outcome of a wound ballistic analysis is dependent on the underlying methodology.

For instance, CT and MRI technology, unlike common photography, enables one to better visualise and analyse the precise trajec-

\footnotetext{
${ }^{85}$ Ibid., pp. 711, 714.

${ }^{86}$ See for all these techniques, M.J. Thali, 'Modern graphical methods', in: B.P. Kneubuehl (Ed.) et al., Wound Ballistics: Springer-Verlag, Berlin, Heidelberg (2011), pp. 289-293.
} 
tory of a bullet and the wound. Whereas CT-scan methods generally produces less detailed soft tissue but more details for bone structure, MRI technology is more suitable - due to a higher resolution image of the soft tissue - to visualize soft tissue and organ damage. ${ }^{87}$

The same relevance for defence counsel to be sensitive to the methodology applied by the forensic expert relates to the difference between X-ray and 3-D technology. ${ }^{88}$

Elements such as the exact entry wound or the precise location of a bullet or metallic fragment can be decisive in a court of law especially when it is, for instance, the prosecution theory that a civilian or number of civilians is killed by a military unit allegedly having fired from a certain direction.

Hence, basic knowledge of the methodologies of wound ballistic can be instrumental for defence counsel.

\section{CONCLUSIONS AND RECOMMENDATIONS}

Forensic sciences at the level of international criminal tribunals and especially the International Criminal Court merit, as this article demonstrates, thorough attention by defence counsel. Adequate knowledge of the basics of forensic sciences and the principles which underpin this discipline enables defence counsel to elicit potential exculpatory information during cross-examination of a forensic expert. Understanding the basics of contemporary methodologies for forensic examination can create an advantage for such defence counsel. The examples which were portrayed in this article, DNA and wound ballistics, attest to this conclusion.

Certain new forensic techniques such as the mentioned probabilistic genotyping can be quite persuasive to determine guilt or innocence. Seen from this perspective and contrary to what the International Criminal Tribunal for Rwanda (ICTR) implied in the case against Musema, forensic evidence can have an impact on the probative value of the evidence. In the Musema case the Trial Chamber ruled that '...the absence of forensic or real evidence shall in no way diminish the probative value of the evidence which is provided to the chamber.... 89

${ }^{87}$ Ibid., p. 288.

${ }^{88}$ Ibid., pp. 287, 289-290.

${ }^{89}$ Prosecutor v. Alfred Musema, Judgement and Sentence, Trial Chamber I, ICTR96-13-A, 27/01/2000, para. 52. 
This article may demonstrate that the chamber's view that '...in particular, the absence of forensic evidence corroborating eye-witness testimony shall in no way affect the assessments of those testimonies', ${ }^{90}$ does not have an absolute standing in every criminal case.

Based upon the findings in this article, the following main conclusions and recommendations can be discerned for defence counsel appearing before international tribunals such as the ICC:

i. The chain of custody needs to be properly recorded so it can be assessed by judges and lawyers in court;

ii. The expert independence needs to be guaranteed and tested in court;

iii. The defence needs to have access to original material/crime scene when possible in order to be able to have alternative theories tested by forensic experts as well as to verify 'scientific bias';

iv. Verification and testing of the applied forensic methodology is essential;

v. The defence needs to have knowledge of basic and new forensic technology/developments.

For the future of defence counsel operating at the ICC and other international tribunals, it could be beneficial to have special training programmes for defence counsel in place in order to further familiarize with the influx of forensic science at these courts from a defence perspective. Only this way defence counsel can optimize its task to ensure the fair trial rights of the defendants.

Challenging and applying forensic sciences in court is nowadays, as this article shows, part and parcel of these fair trial obligations.

As Laroche and Baccard observe, '... the value of forensic science to international criminal tribunals is unquestionable but its use needs to mature in a systematic way in the coming years in order to consolidate its crucial evidentiary role'. ${ }^{91}$

Within this process towards 'maturity' the supervisory role of defence counsel in court, in order to merge the proliferation of forensic sciences within the scheme of fair trial rights of the accused, has to be a prominent one. To this end, said recommendations are yet to be seen as a first step.

\footnotetext{
90 Ibid.

${ }^{91}$ X. Laroche and E. Baccard, supra note 1, p. 494.
} 


\section{ACKNOWLEDGEMENTS}

The author would like to acknowledge the valuable and substantive contribution to this article of Sara Pedroso, case manager at the International Criminal Court and legal assistant at Knoops' International Lawyers as well as the research assistance of Sylvain Clerc, Researcher at Knoops' International Lawyers.

Open Access This article is distributed under the terms of the Creative Commons Attribution 4.0 International License (http:// creativecommons.org/licenses/by/4.0/), which permits unrestricted use, distribution, and reproduction in any medium, provided you give appropriate credit to the original author(s) and the source, provide a link to the Creative Commons license, and indicate if changes were made. 